\title{
Shakespeare's Measure for Measure: The Problem Of Social Reform and Marriage
}

'Why You are Nothing then: Neither Maid, Widow, Nor Wife'

(Measure for Measure, V,i.178-9)

\author{
Farhana Wazir Khan \\ Department of English \\ University of Karachi
}

\begin{abstract}
The article focuses on Shakespeare's play: Measure for Measure, with the aim of bringing to light the central problem of the play which is that of social reform and marriage in an early modern European society. It is a play that has been located against the background of seventeenth century society of London where it was first performed. However, it is symbolically set in the city of Vienna.

Feminist and Historicist critics have been cited in the article in an interpretation of the play which requires a consideration of the role of women and their status in the playworld. The issues of private and public marriages, and the ambiguity governing the laws on marriage, form the complex problem raised in the play. It is the contention of the article that Shakespeare emphasized the need to regulate the legal system with a view to promote greater representation and voice to women who were victimized by the corrupt legal institutions, both religious and official. Thus, the article suggests that the developments in the position of women, and the questions as to whether they were married or single, were the subject of public concern and debate in sixteenth and seventeenth century Europe. Marriage was, therefore, felt to be the most crucial issue in this regard and the aim of the dramatists and literary writers was to popularize the difficulties faced by women with a view to raising the consciousness of the public.
\end{abstract}

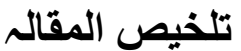

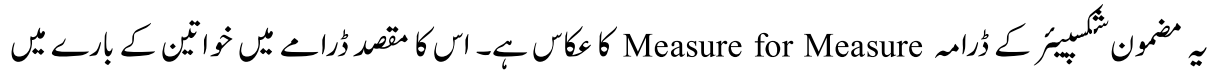

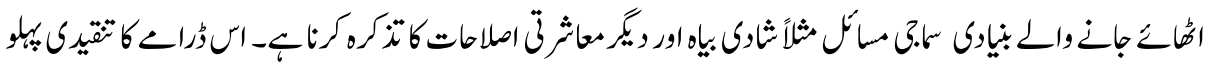

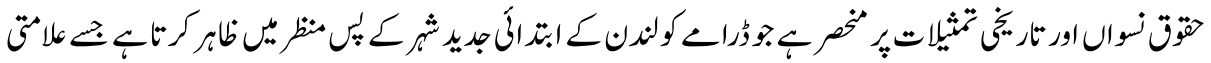

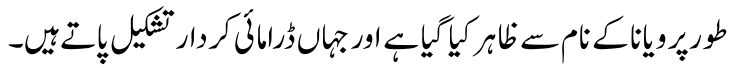

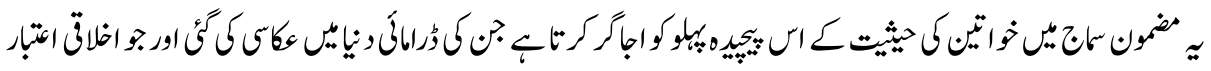

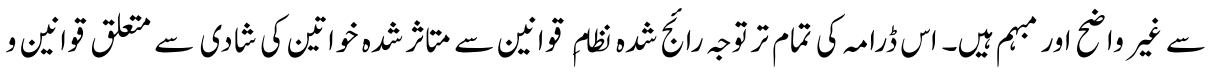

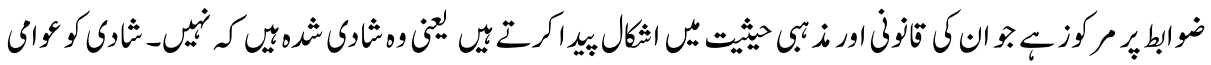

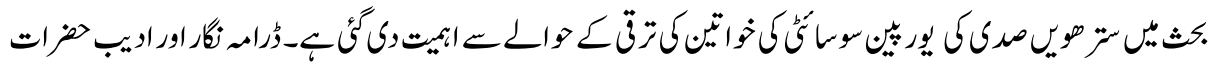

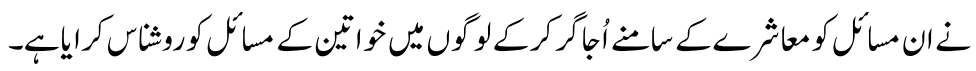


Measure for Measure is a Shakespearean play that has continued to attract the attention of feminist writers to this day as it poses the difficulties surrounding the legal status of complaints by women whose social and marital rights were the subject of controversy at the time. Early modern Europe, particularly England, witnessed an evolution not only in terms of the political structures of society but also in the position of women within the framework of the religious and ethical codes of the era. According to Danielle Clarke, in her consideration of another contemporary play based on a biblical theme, The Tragedy of Miriam, the focus of the dramatists of the age, generally, was on 'marital relationships as microcosm (the contract between two individuals) and as macrocosm (as an image of the reciprocal duties of ruler and subject)' (Crarke, 2006). According to critics, like Sean McEvoy, literary opinion is divided in the interpretation of this problem play. Some critics, on the one hand, have stated that love and marriage are interrogated so darkly in Measure for Measure that it is difficult to ascertain whether Shakespeare wished to promote the concept of utopian sexuality where desire and procreation find their own level, free from legal constraints, or, on the other hand, that he wished to remind his audience of the need to control the destabilizing force of lust outside marriage ( McEvoy, 2000).

However, this article attempts to locate Shakespeare's play in the context of the controversial judgements made by the major protagonists to address the debatable issue of marriage that directly affects the roles of women in a society that seeks to live by the divine injunctions regarding public and private morality. From the beginning of the play, the society of Vienna is portrayed as hypocritical in its sexual practices and familial behaviour. The most direct implication of this confusion is felt to be the complex issue of marital law which is the main subject of all the characters speeches. Official attitudes towards women become the criterion by which the governance of this society is judged.

The ruler of this state is the Duke of Vienna who confesses that his government has allowed the people to violate the 'strict statues and most biting laws' (I,iii, 19), for 'fourteen years' with the result that sexual promiscuity and libertinism have undermined the institution of marriage. It is no coincidence that there is no happily married character in the play. This neglect of the law regarding the women's right to achieve a stable marital bond, considered to be the only viable option within the play, presents a paradigm of the general disintegration of society at large where the weak and economically underprivileged women, either of single status or those of easy virtue, are exploited due to the ambiguity governing the laws of marriage. Marriages are deemed to be dubious due to the confusion in laws governing the private pledge of marriage, which is thought to be binding but not to be consummated until sanctified by the church in public.

Thus, there exists the anomaly of marriage contracts that are accepted as 'true contracts'(I,ii,134), or sponsalia de praesenti, in which a woman like Julietta is considered to be Claudia's 'wife', and yet lacks an outward church 
'denunciation'(I,ii,137), that would legitimize their physical union. Nevertheless, the young couple who have waited for the 'propagation of a dower' (I,ii,139), before declaring their contract in front of witnesses, have engaged in 'mutual entertainment'(I,ii,143), with the result that Julietta is pregnant. Angelo, the deputy who has been given the charge of reforming his society in the supposed absence of Duke Vincentio, the ruler of the city state, embarks on a crusade against 'fornication' and chooses to make an example of the young hapless couple who have been caught transgressing the boundaries of an ambiguous law.

However, rather than the confused couple, it is the state of "Vienna [which] appears as a place without appropriate laws, and the very lack of good laws locks its central characters into their several and separate, but analogous prisons' (Garber, 2004). Given the confusion in the marital laws, Angelo has the power to pardon or punish the guilty pair, yet he chooses to disregard the pleas of mercy and execute his dire vengeance against the young man by ordering his execution. Isabella, a nun and sister of the accused is brought to plead Claudio's case but is herself propositioned by the 'outward-sainted' (III, I, 88) Deputy who solicits her in a sadistic manner, in a startling attempt at rape and blackmail. Unless she submits to the Deputy her brother's life is 'forfeit'.

It is only later that we discover that the seemingly strict Deputy had also been guilty of betraying his vows to his jilted fiancé, Mariana: 'Partly for that her promised proportions/ came short of composition; but in chief/ For that her reputation was disvalued/ In levity..' (V,i,218-221). As punishment for Angelo's hypocrisy, the Duke who observes all these actions in the disguise of a Friar, connives at a bed trick in which the aggrieved woman disguises herself to deceive her contracted husband and take the place of Isabella. Thus, according to the law, Mariana makes it binding on Angelo to adhere to his marriage vows regardless of his unwillingness or face the punishment of death himself. It appears that marriage is the only way for Mariana to salvage her lost honour and that the vows she had once made with Angelo, dismissed by him as 'some speech of marriage' (V,I,216), cannot be broken, whatever, the cost. At the same time, the convoluted plot of the play also exposes the vulnerable position of single women, like the innocent Isabella, who are threatened by accusations, against the integrity of their reputation, which enables the predatory men, like Angelo, to abuse or abandon them. Thus, women are victims not only of their recalcitrant husbands, but also of the law that enables the contracted husbands to leave them on the basis of allegations against their wives' 'honour'. Even then, there is no recourse for women, like the pregnant Julietta and compromised Mariana, to get redress for their wrongs and gain their freedom. Indeed, they are liable to be tortured by the other Deputy, Escalus, who promises to 'go darkly to work' (V,I, 277), on them with the aim of extracting a confession from them as to the identity of their alleged instigator. In this way the women who are victims are made into criminals themselves, and 
'suborn'd', (V,I,304), by the political strategies of other men. Clearly justice is not accessible for women in the society depicted.

The several references to marriage 'proportions' or the 'dowry' refer to another predicament for the women in this play world of materialistic and greedy populace. If women cannot provide their husbands with the promised 'proportions', then they lose their opportunity to get married as revealed in the admissions of Claudio and Angelo. The only other way the women of the city survive is in the role of prostitutes symbolized by the degraded and much abused 'Mistress Overdone'. She is also shown as a central figure in an exploitative industry that trades profitably from the services of her 'bawds'. According to Gary Taylor, by concentrating on the Deputy and his affairs, Shakespeare distracts attention from the real focus of sexual corruption which is Viennese prostitution. The historical reason for this displacement of social criticism is the actual underworld of London's sex trade in Shakespeare's time. This ruthless exploitation of women became increasingly an aspect of the city where 'female raw material was fished up from the widening pool of displaced and destitute families caused by agricultural contraction, periodic commercial recessions, plague and conscriptions for war...persistent decline in wages..[and] the rise of capitalism that made more families vulnerable economically, at the very time when political and demographic change tended to isolate individuals from earlier mechanisms of social protection, and organized charity (Taylor, 1989). Marriage is the only way for women to safeguard their social and economic rights as depicted in Shakespeare's play. Historical accounts show that in England, women had to support themselves even after marriage with some marketable product of their domestic labour, in a variety of crafts and trades, 'the most frequently mentioned trade for women, however, was housewifery' (Rackin, 2005). When women fail to achieve the status of good wives, their roles become morally suspect and liable to be attacked. This is indicated in the pun on the word 'nun' when Isabella declares herself to be so, she is reminded that she is nothing if 'neither maid, widow, nor wife' (V,I,78-79). The view is supported by Shakespeare's feminist critics like McLuskie. She finds in his other play, King Lear, also, a 'narrative and its dramatization' which presents a connection 'between sexual insubordination and anarchy, and the connection is given an explicitly misogynist emphasis' (McLuskie, 1994). Women without male protectors are epicted as being devoid of any legal security, which leaves them no choice but to comply with all the demands of the men who are considered to be their affianced 'husbands' and yet not fully so in legal terms.

It is this dilemma of women caught within the bonds of proposed matrimony and yet accused of pre-marital sex that forms the central paradox of the play. According to Stephen Greenblatt, the entire play affords a vision of forced marriages as 'Mariana insists on marrying the repellent Angelo, who has continued to lie, connive, and slander until the moment he has been exposed. In the same strange climax Duke Vincentio..who seeks to control his subjects' sexuality proposes marriage with Isabella [Claudio's sister], 
who has made it abundantly clear that her real desire is to enter a strict nunnery. As if this is not enough, the Duke punishes the scoundrel Lucio by ordering him to marry a woman he has made pregnant' (Greenblatt, 2004). It appears that women have to marry perforce and acquire the status of wives, or as a last resort, become prostitutes. Isabella's decision to become a nun is not seen to be inviolable either, as she is afforded no protection by her habit.

The Duke has also arrived at the conclusion that the first step to take in reforming society is to rectify the problems of the status of women in his city. When he takes on a disguise as a Friar, it is to defend the rights of the women who are exploited like Julietta, Mariana, and the prostitutes in this play-world. Isabella, who attempts to escape the power of men in her life by retreating to the nunnery, until she is called to save her brother Claudio's life, is also implicated in the power play of the men who seek to manipulate her (McEvoy, 2000, p.228). The Duke realizing his past complicity in the evils of his society, either through his sins of omission or commission, accepts that he has brought his state to the edge of moral chaos. Before he can embark on any plan of reform, particularly in the cases of women he helps, he has to expose all the corruption present in his city. His belief is that 'there is so great a fever on goodness that the dissolution of it must cure it. Novelty is only in request, and it is as dangerous to be aged in any kind of course as it is virtuous to be constant in any undertaking' (Ill,ii,216-220).

The above lines provide the most convincing reasons for the Duke's judgements and conduct throughout the play. They are the key to his motivations in first relegating the task of governing his city to Angelo and his secondary Escalus, and then in observing them in the guise of a 'friar' to outwit them in every measure they take. It is obvious to the Duke that his own rule has lost its credibility and his assistants in the oligarchy have contributed, each in his way to the failure of government. When the Duke sets out to give absolute power to his deputies, he desires to reveal their flaws as the most glaring proof of their hollowness and pretences. By destroying their false images, he aims to purge Vienna from the 'fever' corroding the body public. This disease is so widespread that the only physic to be administered is the dissolution of the entire structure of values and principles governing the state. Only a radical change of this nature can restore the Duke and his state to a viable existence.

To this end, the ruler has to satisfy the demand for change and novelty by transferring power to men who represent conflicting interests and ideologies. By exposing the fallacies in Angelo's hypocritical approach, he intends to teach the people an object lesson in loyalty and fidelity to their true ruler and he starts by addressing the grievances of women. Both Angelo and Escalus fail to be constant to the religious ideals, of either 'mortality and mercy' $(\mathrm{I}, \mathrm{i}, 44)$, that they had initially been deputed to minister. Their respective virtues of justice and mercy are in reality excuses which they offer to hide 
their own deep inner flaws of character. Angelo's severity in translating the laws of the state, is an expression of his egoistic and vengeful personality for he does not satisfy the essential quality for establishing justice:

He who the sword of heaven will bear

Should be as holy as severe:

Pattern in himself to know,

Grace to stand, and virtue go:

More nor less to others paying

Than by self-offences weighing (III,ii,254-259).

Angelo's lack of grace and virtue is amply demonstrated in his decisions which are neither impartially balanced in the scales of justice, nor do they arise from an awareness of his own shortcomings towards the women he has harmed, a fault he never acknowledges until his public exposure. Most notably his administration does not redress the wrongs which the legal and judicial anomalies have perpetrated against the marriages of women in Vienna. He inculcates no admiration for his seemingly just decisions because his concept of justice is not based on spiritual and temporal ideals that enable humanity to achieve its potential. Indeed, he defeats the very cause of social reform he aims to serve and does exactly what Escalus had warned him against: 'Let us be keen, and rather cut a little/Than fall, and bruise to death' (II,1,5-6).

This metaphorically demonstrates the destructive quality of Angelo's methods of judgement. Reform entails an education in morals and awareness of values that transcend material expediency. But he only alienates his subjects as Claudio's fear of death amply shows. Claudio's sentence is an imposition to which he cannot be reconciled and his spiritual state is not improved either as evident in his appeals to Isabella to sacrifice her own chastity for her brother's sake. He does not comprehend his responsibility in taking advantage of Juliet. Neither does he or any convicted criminal in the play evince a deep felt regret that offers hope of forgiveness and redemption from eternal punishment. Their worldly penance and expiation provides no corrective for their sinful conscience and thus their punishment fails to achieve its ends in moral reformation.

Although, the exercise of mortal punishments are not carried out properly, the abrogation of punishment by the letter of the law also does not necessarily indicate a state of spiritual well-being in society because the hidden iniquity still prevails. Nor does it fulfill the need for true mercy as it is possible to consign the guilty souls to damnation by depriving them of the means of atonement and redress afforded by repentance through suffering in this temporal existence. The guilty are not able to achieve 'Grace' for a mere reprieve by a temporal judge cannot grant them this spiritual blessing. This is evident in the scorn with which Pompey, the pimp or servant to the bawds, responds to Escalus's earlier mild reproof and acquittal. 
1 thank your worship for your good counsel; [aside] but I shall follow it as the flesh and fortune shall better determine (II, i,24925|).

Similarly Claudio's pardon is perceived by the Duke as issuing from Angelo's own guilty secret which confers no dignity either to the judge's mercy, nor does it restore Claudio's honour without which his life is prolonged by shameful devices: 'When vice makes mercy, mercy's so extended/ that for the fault's love is th' offender friended (IV,ii,110111).

This is a fair description of the entire plot of the play and clarifies the Duke's role in the final scenes of the play. As the only true authority in the world of the play, it is the duty of the Duke to reveal 'evi1... wrapt upt in countenance' V,i,120-121), that is 'making practice on the times' (III, ii, 267). To this end he contrives Angelo's deception by Mariana, his contracted wife whom he had repudiated on ostensibly false charges of illrepute. By substituting for Isabella, Mariana consummates her 'old contracting' (II $1,11,275)$ at the behest of the Duke: 'the doubleness of the benefit defends the deceit from reproof' $(111, \mathrm{i}, 256-259)$. It is the judgement of the Duke in his friar's guise that Mariana must make Angelo fulfil his pledge and complete the terms of his public oath, which made Angelo her 'combinate husband'. The only act needed to heal this rupture is, in the Duke's judicial view, the very union which Claudio and Juliet stand guilty of completing, according to Angelo's sentence. Thus, while Claudio and Juliet are alleged to have unknowingly broken the law by their 'promise and act which made them man and wife', Angelo unwittingly conforms to the law by transforming his contract of per verba de future into an actual marriage by taking his affianced wife to bed even though he was labouring under the delusion that it was an intentional act of rape committed against the novice, Isabella. This convoluted exchange of oaths and beds is employed to emphasize the Duke's conviction that a woman's right on her husband is absolute, regardless of his behaviour and all is excused in the advancement of this claim: ' the justice of your title to him, Doth flourish the deceit.... (IV, i,74-75).

The sanctity of the marriage contract is upheld and considered indissoluble. Unfortunately Claudio's and Juliet's contract lacks this official sanction because of its clandestine nature, even though it is indubitably legal as evidenced by the Duke's final command to Claudio: 'She, Claudio, that you wrong'd, look you restore' (V, i,522).

It is significant that Claudio is not ordered to marry Juliet. Presumably their marriage is already an accomplished fact by their sexual union. What the Duke regards as wrong is the secrecy with which they contracted their union, for Claudio has to restore Juliet to her dignity and honour by openly endowing her with the place and position of his wife. This acknowledgement is necessary after Claudio's abuse of Juliet's love for him which culminated in their attempt to hide their union. That this unsuccessful subterfuge is 
motivated by desire for Juliet's dower, is no doubt a reflection of Claudio's lack of discretion in taking advantage of his betrothed 'wife' before giving her the protection of his name publicly. It Is not fornication, of which Claudio is guilty but irresponsibility towards his duties as a husband. The Duke, as friar, admonishing Juliet claims she: 'Hath blistered her report. She is with child" (II,iii,12). He reminds her of her own responsibility for causing Claudio's imprisonment and also her child's shame in being born in such dubious circumstances. His emphasis is on the 'sin' she carries (II,iii,19), and on the fate of her partner who 'must die' (II, i ii, 37). Apparently, the friar is teaching her a lesson by forcing her to face the consequences of her 'mutually committed' act (I I, i i i, 27). Her sin is of a 'heavier kind' (II,ili,29) than Claudio's, in the sense that she has to endure the combined weight of the world's disapproval and heaven's displeasure for the remainder of her life since she is not offered the comfort of expiation in the physical form of death. Her burden is of an emotional and public sense of shame and spiritual 'horror' (II,ill,42), that is worse than dying. Comparatively, her partner is to receive a lighter sentence because death is described as a solace in his tormented earthly existence. For him death will be a liberation from the 'thousand deaths' (III, i,40), that life is afflicted with. Yet, at the same time it is also arguable that Claudio was more erred against than erring due to the bad laws governing marriage.

The Duke is therefore in a position at the end of the play to reject these abuses of justice and mercy and establish what he considers to be the truest approximation of these elusive ideals. He has, in Isabella's admiring words, administered 'a physic Thats bitter to sweet end' (IV,vi,7-8). Contriving an exposure of both his 'supporters' (V,i,19), in the business of government affords the Duke a valuable opportunity to exercise his judgement in a manner that will vindicate him before his subjects and provide a chance to question the credibility of all rival powers in his state. The absence of integrity in the judge substituting for the Duke is revealed when he is reminded: 'Then, Angelo, thy faults [are] thus manifested' (V, I, 410). Here the 'precise' Angelo is paid back in the same coin which was his currency when he is openly denounced as a murderer and rapist by women who had long been the target of his contempt and hostility. It was Isabella who had previously suffered the slanders uttered so casually by the Deputy as 'fornicatress' and an instrument of some mightier member. He had denied the women an identity as human beings in their own right. His allusions to these women, indeed all women, had a dehumanizing quality that was an indication of an aspect of his own character which he sought to hide, recognizing it to be demeaning to his great eminence. Thus, through his character, Shakespeare represents the men who pretend to establish their supremacy over all human emotions and instincts by oppressing women, very like Milton's Satan who tempted Eve, but also craves a veneration he has forfeited by his defiance of divine omnipotence. The Duke ironically refers to these pretentions in his deputies: 'Respect to your great place; and let the devil/ Be sometime honour'd for his burning throne' (V,1,290-291). 
After Isabella and Mariana have openly proclaimed Angelo's viciousness, Escalus loses no time in asserting his presence, as if to fill the void left by Angelo's disgrace. But the Duke contrives Escalus's discomfiture by denouncing the state and its 'unjust' rulers in his guise as Friar Ludovick, only to appear in his ducal magnificence when Escalus tries to also have him arrested. Duke Vincentio's disguise as a religious figure, the friar, also affords him the opportunity to pass judgement on his own past conduct as the ruler of Vienna. This stratagem enables him to criticize his former negligence in the administration of justice, with impartiality and objectivity. Otherwise a public confession of his guilt would no doubt have entailed some measure of humiliation and loss of dignity before his subjects. But his friar's persona lends him the advantage of speaking on behalf of those who have suffered injustices and also dissociates him from the abuses of his own Deputy, while at the same time presenting himself as the champion of the cause of truth and righteousness. When he accuses the Duke of betraying the most elementary principle of justice, in appointing the accused man, Angelo, as the judge of his own cause, Vincentio is in fact condemning his previous esteem of this 'seemer'. No doubt he always had reservations about his deputy, but Angelo nevertheless enjoyed a privileged position of honour and power. Meanwhile the state of Vienna was lamentable and an observer could see 'corruption boil and bubble Till it o'errun the stew' (V, i, 315-317). It is 'To find out this abuse, whence 'tis deriv'd' (V,i,246), that the Duke has to exercise spiritual and temporal authority in disguise and take legal decisions which critics have regarded as 'outrageous'. Critics find his manipulation of his subjects and assessment of their cases reprehensible in the Duke.

Harold Goddard also finds it difficult to make the Duke morally acceptable. His solution to the problem is to either consider the Duke's whole plan as a sort of play within a play to catch the conscience of his deputy - and of the city or to view him as a demi-god (Goddard, 1951) but Goddard concedes that the play is 'too intensely realistic to make that way out of the difficulty entirely satisfactory. Marjorie Garber finds a historical resemblance in the Duke with the figure of James I, who ruled England's throne when the play was performed, and who made it a habit of spying on his people. 'The motif of the disguised ruler', who conceals his identity may be an allusion to 'James who was associated with the idea of power in absence, the keystone and cornerstone of absolutist power' (Garber, 2004, p.564).

When we analyse the play-text, however, it is clear that the Duke himself voices this disapproval of his own manoeuvres which he admits would make ever, the most constant subject 'blench' (IV, v, 5). His rival adversary in this battle for political and ideological survival, is formidable and he has no option but to 'veil full purpose' (IV,vi,4), and use 'Craft against vice' ( I, ii, 270). This vice is above all that of hypocrisy that seeks to support the pretensions of its practitioner. Angelo professes a saintliness that he regards 
with pride. His claim to be revered is on par with any human ambition to ape divine perfection. Isabella condemns this ludicrous effort to embody the divine in an all too animal form in these resounding lines describing man: 'Iike an angry ape/ plays such fantastic tricks before high heaven/ As makes the angels weep (11,ii,121-123).

The Duke on the other hand deprecates any attempts to deify himself and even rejects the 'Aves vehement' $(1,1,70)$, of his people. His aim is limited and thus realizable; the object of his efforts being to confound the forces of anarchy and dissolution threatening his state and by extension his own identity. These forces of destruction are personified by his own political subordinate, Angelo who has completely lost any distinction between crime and justice in his enjoyment of power and is himself guilty of sexual vices he condemns.

It has been brought home to the Duke that the law and its institutions are possible only by regulating the sexual force in its citizens who must be given clear encouragement and warnings to achieve order in place of anarchy. This is accomplished by devoting a greater attention to the bonds of matrimony which had been consigned to confusion by neglect towards their requirements. Isabella's response to the Duke has also to be considered in the light of these ethical, physical and emotional imperatives. She too has encountered the conflicting demands of physical desire unchecked by legal and moral restraints. Besides her narrow escape from the violent threat of Angelo's proposal which in part she acknowledges to be her own responsibility ( $\mathrm{V}, \mathrm{i}, 444-445)$, she has been confronted by the sexual licence of her brother and her friend Juliet. She cannot afford to be complacent about her own immunity from human impulses. Her consistent faith in the authority of the Duke also prepares the audience for a response that is favourable to the Duke's offer when he tells her 'What's mine is yours, and what is yours is mine' (V, I, 534). Both social and political authority is suggested in this marriage, indicating how the Duke is himself, finally, ready to share his power with a woman whom he hopes to wed.

However various performances have explored the diverse reactions that are implied by her silence in the play text. But dramatic force of the previous scenes lend weight to the argument that her strong and passionate voice, in support of both justice and mercy, cannot be relegated behind the walls of the Nunnery. Her character manifests the Duke's advice that virtues should go forth and that 'virtue is bold and goodness never fearful' $(111,1,208)$. The course she had embarked upon when she left the confines of her sanctuary render the difficulties, in retreating from the claims of the world insurmountable. Were she to return, Isabella would waste the potential for assisting her Duke to administer 'a physic/ That's bitter to sweet end' IV,vi,7-8), in the interest of a just and good government. Her abilities are amply demonstrated when Isabella's commitment to the claims of justice make her willing to sacrifice her most valued sense of reputation by publicly appearing to denounce Angelo. Then again, she overcomes her own desire for vindication and decides to sue for a merciful treatment of Angelo, at the request of his 
betrothed wife Mariana, despite his evil intents which he had failed to act upon. It appears that intents alone do not deter her from arguing her case by utilizing the loophole offered by the excuse: 'His act did not'o'ertake his bad intent/ And must be buried but as intent/ That perish $\mathrm{d}$ by the way. Thoughts are no subjects'/ Intents, but merely thoughts $(\mathrm{V}, 1,449-452)$.

Isabella's developing sense of maturity is evident in this legalistic plea. It is remarkable for its practical judiciousness and contrasts with her earlier harping on absolute mercy, in disregard of the law. It is another matter that her defence is irrelevant to the facts of the case, because of her ignorance of Claudio's escape from Angelo's deliberate orders for his premature execution. Nevertheless, Isabella's final words in the play emphasize the difference between thoughts for which we are not accountable and external acts that alone are cognizable, for the purposes of this world and its legal systems. Isabella, as the most active female character of the play, shows her devotion to both justice and mercy as well as her growing acumen in the processes of the law.

Her silence to the Duke's proposal of marriage at the end of the play, after all can be resolved. It may on the one hand be interpreted as a noncommittal response that may suggest either the possibility of an acceptance or on the other hand, a rejection. But she cannot be judged on the basis of these unuttered thoughts. The estimate of her true character has to be on the basis of her actions in the play. Shakespeare has thus defended his heroine from any charges leveled against her presumed inclinations, whatever their nature, unless they be supported by her deeds. Her honour is indeed well-defended. Shakespeare's play thus implies that if a society is to be based on justice it must be able to provide the women of the state a voice and position of some authority according to the moral and religious laws designed to guarantee their security.

\section{References}

Clarke, Danielle (2006) "The Tragedy of Miriam and the Politics of Marriage" in Early Modern Drama: A Critical Companion eds. Jr., Garrett A. Sullivan, Cheney, Patrick and Hadfield, Andrew, Oxford, UK, Oxford University Press, pp.248-259.

Garber, Marjorie (2004) Shakespeare After All, New York, USA, Anchor Books, p. 568.

Goddard, Harold (1951) "Measure for Measure" in The Meaning of Shakespeare, Chicago, USA, University of Chicago Press.

Greenblatt, Stephen (2004) Will in the World: How Shakespeare became Shakespeare, New York, USA, W.W. Norton, p.136. 
McEvoy, Sean (2000) Shakespeare: The Basics, London, UK, Routledge, p.228.

McLuskie, Kathleen (1994) 'The Patriarchal Bard: Feminist criticism and Shakespeare's King Lear and Measure for Measure' in Political Shakespeare: Essays in Cultural Materialism, edited by Dollimer, Jonathan and Sinfield, Alan second edition, Manchester, UK, Manchester University Press, pp88-108 (98).

Rackin, Phillis (2005) Shakespeare and Women, Oxford, UK, Oxford University Press, p.35.

Taylor, Gary (1989) Reinventing Shakespeare: A Cultural History from the Restoration to the Present, London, UK, The Hogarth Press, p.389.

Dr. Farhana Wazir Khan is Assistant Professor in the Department of English, University of Karachi. 